\title{
Imigrantes e fazendeiros no alvorecer da indústria paulista: a formação da Cia. Mecânica e Importadora de São Paulo (1882-1892) *
}

\author{
Gustavo Pereira da Silva **
}

\begin{abstract}
Resumo
Em que pese o crescimento recente do campo história de empresas no Brasil, ainda permanecem lacunas sobre como e quem constituiu algumas das grandes firmas nacionais presentes no início do avanço industrial paulista, caso da Cia. Mecânica e Importadora de São Paulo, criada em 1890 na capital paulista. Dessa forma, o artigo busca mostrar que na formação da maior empresa de bens de capital paulista do final do XIX e décadas iniciais do século XX, a Cia. Mecânica e Importadora de São Paulo - a partir da incorporação da Lacerda, Camargo \& Cia. e da Engelberg, Siciliano \& Cia. - concorreram tanto nacionais quanto estrangeiros, que comandavam as empresas que foram incorporadas. Para tanto, utilizaremos demonstrações financeiras, relatórios, contratos e atas das seguintes empresas: J. Arbenz \& Cia.; Lacerda, Camargo \& Arbenz; Lacerda, Camargo \& Cia; Cia. Mecânica e Importadora de São Paulo, além de anúncios do jornal Correio Paulistano no período 1882-1893.
\end{abstract}

Palavras-chave: Indústria, Imigrantes, Fazendeiros, São Paulo.

\begin{abstract}
Immigrants and farmers at the dawn of São Paulo's industry: the formation of the Cia. Mecânica e Importadora de São Paulo (1882-1892)

Despite the recent growth in the field of corporate history in Brazil, there are still gaps regarding how and who constituted some of the major national firms present at the beginning of the industrial advance of São Paulo, such as the Cia. Mecânica e Importadora de São Paulo, created in 1890 in the state's capital. Thus, the article seeks to show that in the formation of the largest goods company in São Paulo's capital from the late nineteenth and early twentieth century, the Cia. Mecânica e Importadora de São Paulo - from the incorporation of Lacerda, Camargo \& Cia. and of Engelberg, Siciliano \& Cia. - competed with both national and foreign firms, who led the companies that were incorporated. To do so, we will use financial statements, reports, contracts and minutes from the following companies: J. Arbenz \& Cia.; Lacerda, Camargo \& Arbenz; Lacerda, Camargo \& Cia; Cia. Mecânica e Importadora de São Paulo, as well as newspaper reports from the Correio Paulistano in the period 1882-1893.
\end{abstract}

Abstract: Industry, Immigrants, Farmers, São Paulo.

JEL N96, N86, N76.

\section{Introdução}

A década de 1880 foi considerada pela historiografia econômica como o período da gênese da indústria na província de São Paulo (Cano, 1981, p. 69; Aureliano, 1999, p. 30; Mello, 2009, p. 82; Suzigan, 2000, p. 48; Silva, 1995, p. 94). Com as altas cotações do café no mercado internacional, em um ciclo ascendente que foi de 1886 a 1894, houve o vazamento do

\footnotetext{
* Artigo recebido em 13 de janeiro de 2019 e aprovado em 15 de janeiro de 2020. O trabalho teve financiamento da Fundação de Amparo à Pesquisa do Estado de São Paulo (Fapesp) no processo 08/50917-0.

${ }^{* *}$ Professor do Departamento de Economia da Universidade Federal de São Carlos (UFSCar), Sorocaba, SP, Brasil. E-mail: gusttavopereira@ yahoo.com.br. ORCID: https://orcid.org/0000-0003-0227-2643.
} 
capital do núcleo deste complexo econômico - as lavouras do Oeste Paulista - para as atividades complementares: comércio de importação e exportação, bancos e seguros, serviços públicos, ferrovias e, também, a indústria (Saes, 2002, p. 185; Delfim Netto, 2009, p. 278).

A relação com o café está na síntese explicativa do surgimento da indústria paulista elaborada originalmente por Dean (1971). Ele também enxergava o quadro da década de 1880 como o momento da formação da indústria paulista pois expandira-se a demanda estadunidense pelo café brasileiro, fato que impôs a necessidade de resolução do problema da mão de obra por parte dos fazendeiros e do governo provincial: o estímulo à entrada de imigrantes europeus às terras paulistas, sobretudo italianos ${ }^{1}$.

Estes imigrantes não ficaram restritos à figura de colonos que laboravam nas fazendas paulistas. Alguns envolveram-se no comércio de importação, com vistas ao atendimento de uma demanda das camadas médias e baixas - formada em boa medida por imigrantes - e que tentavam mimetizar os padrões de consumo da elite paulista, baseados na utilização de gêneros importados. Ademais, estes imigrantes-comerciantes respondiam pela importação de equipamentos agrícolas, por exemplo, máquinas para o beneficiamento de café (Oliveira, 2014, p. 190).

Para Dean (1971, p. 25-39), a figura do imigrante-importador está na composição da matriz social do industrial paulista - ao lado da elite agrária - em virtude de três fatores ${ }^{2}$. Primeiro, a atuação como importadores de manufaturas, muitas vezes, impunha a necessidade de finalizar bens que chegavam semiacabados, além de ficar a cargo do importador a manutenção destes produtos no Brasil, contando com sua prévia expertise industrial adquirida na Europa. Segundo, era frequente que este imigrante tivesse ligações - até mesmo familiares - com fontes creditícias na Europa e Estados Unidos, o que viabilizava a montagem dos negócios na América do Sul. Por fim, o estreito relacionamento entre fornecedores (Europa e Estados Unidos) e importadores (Brasil) impelia os últimos a transformarem suas agências de importação em fábricas autorizadas, estabelecendo os imigrantes como industriais no Brasil, tendo como exemplos as figuras de Francisco Matarazzo (Indústrias Reunidas Francisco Matarazzo) e Alexandre Siciliano (Companhia Mecânica e Importadora de São Paulo) - ambos de origem italiana.

Em relação aos fazendeiros, Dean (1971, p. 43-44) aponta que uma parte destes agentes já tinha uma expertise empresarial, pois vários dos empreendimentos necessários ao negócio cafeeiro - ferrovias, bancos, firmas comissárias, casas de importação e exportação - tratavam-

(1) Entre os anos 1855-1887, pouco mais de 81 mil imigrantes entraram na província de São Paulo pelo porto de Santos. Porém, entre 1887-1920, este número foi de mais de 1 milhão e 609 mil imigrantes. Este aumento da imigração em São Paulo se coaduna aos dados nacionais, visto que, entre 1884-1940, mais de 4 milhões e 100 mil imigrantes entraram no Brasil, sendo que o maior grupo foi de italianos (34\% do total), seguido dos portugueses (29\% do total) (Schwarcz, 2012, p. 67; Rocha, 2007, p. 74).

(2) Ressaltamos que o artigo tem como foco a abordagem das origens da indústria paulista, em que a bibliografia denotou a transição do imigrante a industrial. Todavia, em outros Estados este modelo não necessariamente se aplica, por exemplo, como demonstra Birchal (1998), ao indicar que eram brasileiros natos a maioria dos empresários têxteis registrados nas Minas Gerais na segunda metade do XIX. 
se de sociedades anônimas em que boa parte das ações estavam nas mãos da elite agrária. Neste sentido, Dean (1971, p. 44) afirma que "O desejo de tornar mais lucrativas as propriedades agrícolas foi, igualmente, uma das molas dos primeiros empreendimentos manufatureiros" em que adentraram os fazendeiros. Em tais empresas - como oficinas para elaboração de máquinas agrícolas voltadas ao café - haveria uma divisão de tarefas entre os dois componentes da matriz social do industrial paulista: o comando técnico ficaria a cargo de imigrantes e seu conhecimento mecânico; aos fazendeiros, por sua vez, caberia a base financeira, com o capital necessário à formação da empresa.

No setor de bens de capital paulista ${ }^{3}$ (empresas de máquinas, oficinas mecânicas e fundições), temos o caso da maior empresa nas décadas iniciais do século XX, criada em 1890, a Cia. Mecânica e Importadora de São Paulo. Segundo o próprio Dean (1971, p. 38), foi uma iniciativa do imigrante italiano "Alexandre Siciliano, que abrira uma fundição em São Paulo, a qual veio tornar-se a maior produtora de máquinas e produtos de metal em todo o Estado, absorveu a companhia importadora Lacerda Camargo". Todavia, de que se tratava a firma Lacerda Camargo?

O mote do trabalho será compreender a formação da Cia. Mecânica e Importadora de São Paulo - doravante CMISP - através da evolução da empresa industrial Lacerda, Camargo $\&$ Cia., desde sua origem, que remete às primeiras iniciativas do caldeireiro suíço João Arbenz na cidade de São Paulo ainda em 1882. No ano de 1884, ele formaria a empresa J. Arbenz \& Cia., caldeiraria situada na cidade de São Paulo que, no ano seguinte, receberia os investimentos dos fazendeiros Joaquim Franco de Camargo Junior (morador de Araras-SP) e Cândido Franco de Lacerda (morador de São Carlos-SP), passando a se chamar Lacerda, Camargo \& Arbenz ${ }^{4}$. Esta composição societária se manteria até 1886, quando o suíço Arbenz decidiu abandonar a empresa que, ainda naquele ano, passou à razão social de Lacerda, Camargo \& Cia. e, em 1887, constituiu-se como uma típica empresa familiar, pois além de Joaquim e Candido, ingressou na sociedade o fazendeiro José de Lacerda Guimarães (Barão de Arary, morador de Araras-SP) - que era cunhado de Joaquim e pai de Candido. Por fim, em setembro de 1890, ela seria incorporada, junto com a empresa Engelberg, Siciliano \& Cia. fabricante de máquinas agrícolas localizada em Piracicaba-SP - para a formação da Cia. Mecânica e Importadora de São Paulo.

O trabalho busca dar uma contribuição ao campo de história de empresas, tendo como estudo de caso a formação da CMISP em meio às origens da indústria paulista. Este objetivo embasa-se na escassez de estudos sobre as origens da CMISP - a maior empresa de bens de capital paulista nas décadas iniciais do século XX -, tendo trabalhos como Dean (1971), Marson (2017), Carone (2001) e Suzigan (2000) arrolado informações sobre a figura de

(3) Leff (1968), Suzigan (2000) e Marson (2012 e 2015) denotam que as empresas originadas no final do século XIX na indústria metalomecânica eram, em sua maioria, resultado da atuação de imigrantes, principalmente dos italianos e alemães.

(4) Localizada na zona da Estrada de Ferro Paulista, vizinha às cidades de Limeira e Rio Claro, Araras foi elevada a vila em 24 de março de 1871 e se tornou uma cidade em 1879. Seus cafezais formados na metade do século XIX produziram 500.000 arrobas de café no ano de 1886, safra que foi a quarta maior da província de São Paulo naquele ano (Milliet, 1982, p. 54). 
Alexandre Siciliano (diretor-gerente da firma) e apontado que a empresa surgiu da incorporação da Lacerda, Camargo \& Cia. e da Engelberg, Siciliano \& Cia, mas sem elucidar como se formaram estas empresas na década de 1880 e como elas atuavam, pontos a serem trabalhados no $\operatorname{artigo}^{5}$.

Ademais, ao inserir-se no campo da história de empresas, o trabalho busca, a partir da documentação primária, elucidar como indivíduos, famílias, elites/grupos locais constituíram seus negócios e as diferentes formas que estas associações empresariais assumiram ao final do século XIX no Brasil - de sociedades comanditárias às sociedades anônimas - tendo como prisma o caso da Cia. Mecânica e Importadora de São Paulo (Barbero; Jacob, 2008; Almaraz; Serrano, 2016; Dalla Costa, 2017).

Para tanto, a base documental é composta de demonstrações financeiras (balanços, demonstrações de lucros e perdas, relatórios da diretoria), contratos e atas das seguintes empresas: J. Arbenz \& Cia.; Lacerda, Camargo \& Arbenz; Lacerda, Camargo \& Cia; Cia. Mecânica e Importadora de São Paulo. Esta documentação foi complementada por anúncios destas empresas no jornal Correio Paulistano. O recorte histórico do artigo está escorado no fato do ano de 1882 ser aquele em que foram constatadas as primeiras notícias sobre o caldeireiro suíço João Arbenz na cidade de São Paulo ainda em 1882, anunciadas no jornal Correio Paulistano. O encerramento da análise no ano de 1892 lastreia-se na documentação arrolada, pois é de 31 de janeiro de 1892 a Demonstração da Conta de Liquidação da Lacerda, Camargo \& Cia., fonte contábil que aponta os termos e valores da negociação que selou a incorporação da Lacerda, Camargo \& Cia. pela Cia. Mecânica e Importadora de São Paulo.

Além desta Introdução, a sequência do artigo tratará da J. Arbenz \& Cia. (1884-1885); na sequência abordará a Lacerda, Camargo \& Arbenz (1885-1886); depois discorrerá sobre a Lacerda, Camargo \& Cia. (1887-1890) e; por fim, abordará a Cia. Mecânica e Importadora de São Paulo (1890-1892). Como fio condutor desta análise estará a ideia de que a complexidade dos negócios industriais, atinentes ao setor de bens de capital no estado de São Paulo do final do século XIX, demandava um atrelamento destas firmas aos fornecedores estrangeiros de máquinas e equipamentos, fato que implicava uma constante ampliação do capital das maiores empresas do setor. Dessa forma, a transição de firmas comanditárias a uma sociedade anônima, exemplificada pela formação da Cia. Mecânica e Importadora de São Paulo, calcou-se na simbiose entre imigrantes (conhecimento técnico) e fazendeiros (capital) no alvorecer da indústria paulista.

(5) De acordo com Marson (2015, p. 760), as cinco maiores empresas do setor de bens de capital no estado de São Paulo no ano de 1907 eram (em ordem decrescente do valor do capital): Cia. Mecânica e Importadora de S. Paulo (5.000 contos de réis), Companhia Mac Hardy (978 mil réis), Bernardo Kuntgen (700 mil réis), Arens Irmãos (650 mil réis) e Carlos Tonani (600 mil réis). Em relação à Cia. Mecânica e Importadora de São Paulo, ela fornecia maquinário às indústrias paulistas, através da produção em sua fundição - tornou-se a maior produtora de máquinas e produtos de metal em todo o estado de São Paulo - e da importação de máquinas procedentes do exterior. Inclusive, em 1917, a firma teria importado: locomotivas, trilhos, carvão, aço, ferro, cimento, óleos, asfalto, canos e tubos, equipamento elétrico, motores a vapor, automóveis e suprimentos para o Exército e a Marinha (Dean, 1971, p. 38). 


\section{J. Arbenz \& Cia. (1884-1885): suíços e brasileiros na produção e importação de máquinas e artigos de ferro}

Os primeiros indícios da presença de suíços em terras brasileiras remetem ao século XVII, quando alguns deles teriam feito parte da Companhia de Jesus e suas missões religiosas na Colônia. Mas, foi no século XIX, a partir das experiências das colônias de imigrantes, que os grupos suíços aumentaram seu ingresso no Brasil. No caso da província de São Paulo, tal imigração pode ser dividida em duas fases: entre 1847-1870, período em que imigrantes de fala alemã foram atraídos pelos contratos de parceria para trabalharem nas lavouras cafeeiras paulistas, sendo o principal núcleo a Fazenda Ibicaba, localizada em Limeira e pertencente ao senador Nicolau Pereira de Campos Vergueiro; e, entre 1870 e décadas iniciais do século XX, quando estes grupos vieram com o intuito de se estabelecerem em colônias organizadas pelo governo central, formando pequenas e médias propriedades nos estados do Sul do Brasil (Oberacker Júnior, 1967, p. 468; Witzel de Souza, 2018, p. 4; Witter, 2002, p. 135).

Em que pese, originalmente, grande parte dos imigrantes suíços terem como destino o trabalho nas lavouras, era cada vez mais comum, sobretudo a partir da década de 1870 - pósGuerra do Paraguai - encontrá-los no meio urbano e em ofícios manufatureiros (Oberacker Júnior, 1967, p. 472). Witzel de Souza (2018, p. 5) aponta a existência de um monopólio por parte de alemães e suíços na província de São Paulo sobre as atividades de: cervejeiros, fabricantes de carroças, curtidores de couro, fabricantes de armas e relojoeiros. Este controle sobre os ofícios manufatureiros se baseava no elevado capital social de suíços e alemães, notadamente os grupos com maior índice de alfabetização entre os imigrantes que se estabeleceram em São Paulo, e que consolidaram esta vantagem, inclusive, construindo escolas voltadas aos seus filhos.

Um dos suíços estabelecidos na cidade de São Paulo naquele período foi João Arbenz ${ }^{6}$. No dia 2 de setembro de 1882, o jornal Correio Paulistano apresentava o relato do fazendeiro Joaquim Carlos Bernardino Silva. Em sua fazenda do Tremembé, no distrito da Cantareira (cidade de São Paulo), o suíço João Arbenz, dono de uma oficina de caldeiraria na capital paulista (localizada na Rua da Estação, número 22), instalou um alambique com o sistema esquentador-condensador - utilizado nas maiores destilações à época - que estava em pleno funcionamento há um mês e demonstrava uma grande eficiência e, por isso, ele recomendava os serviços industriais a outros fazendeiros (Correio Paulistano, 2 set. 1882, p. 3).

Um anúncio no mesmo jornal, de 8 de dezembro daquele ano, traz informações sobre a oficina de caldeireiro de cobre do suíço João Arbenz. Em suas instalações, e apoiado no conhecimento das melhores técnicas vigentes nos Estados Unidos e Europa, ele produzia os

(6) Não existem evidências claras sobre quando João Arbenz - provavelmente Johann - teria chegado a São Paulo. Tentamos cruzar dados através de pesquisa em bases genealógicas, mas não encontramos resultados concretos que apontem o ano em que ele aportou em terras brasileiras. Todavia, sua nacionalidade suíça é comprovada tanto pelos contratos da Lacerda, Camargo \& Arbenz, quanto pelos anúncios de seu nome no jornal Correio Paulistano, pois nestas duas fontes consta seu nome como de nacionalidade suíça. 
seguintes equipamentos: máquinas voltadas à produção de aguardente (como os alambiques); retificadores para licores, bacias, tachos, caldeiras, ralos para tina de cerveja, filtradores, louça de cobre, bacias para banho, banheiras, canos de cobre para telhado e esgoto; artigos de metal (torneiras, tinas de fermentação, canos de água, parafusos, válvulas). Ademais, constava a informação de que os materiais e ferramentas utilizados vinham da Europa, permitindo a Arbenz executar os mais diversos tipos de consertos em sua oficina (Correio Paulistano, 8 dez. $1882)^{7}$. Este último ponto - em concordância com os apontamentos de Dean (1971), Marson (2017), Leff (1968) e Suzigan (2000) - mostra que o suíço João Arbenz era mais um imigrante que da necessidade de consertar maquinário importado teria constituído sua oficina e, em um segundo passo, tornava-se um agente do setor de bens de capital paulista.

Na edição de 25 de agosto de 1883, o jornal Correio Paulistano estampou um testemunho da empresa carioca C. Schumann \& Cia. - fabricante da Água de Seltz (água gaseificada) - testemunhando que há três dias o suíço João Arbenz, proprietário de uma grande oficina de caldeireiro na cidade de São Paulo, esteve na capital do Império para montar um aparelho - o Retificador - a ser usado no processo de destilação. Segundo a contratante, tratavase de um moderno maquinário e de grandes dimensões, cuja montagem era prova da boa capacidade e conhecimento de Arbenz, fato que devia ser levado em consideração por fazendeiros e diretores de engenho para contratar os serviços da oficina paulistana (Correio Paulistano, 25 ago. 1883, p. 3).

No dia 5 de fevereiro de 1884, o suíço João Arbenz e o fazendeiro Joaquim Franco de Camargo Junior - morador da cidade paulista de Araras - firmaram uma sociedade em comandita com o nome de J. Arbenz \& Cia., localizada na cidade de São Paulo ${ }^{8}$. O objetivo da empresa era a fabricação e importação de máquinas, aparelhos, instrumentos e materiais para todas as indústrias e para qualquer outro ramo de negócio que convier. O capital da firma era de 40 contos de réis (equivalente a 3.503 libras esterlinas) ${ }^{9}$ foi constituído dos 20 contos de réis fornecido por Joaquim Franco na condição de sócio comanditário e, como sócio comanditado/solidário, o suíço João Arbenz somou seus 20 contos que vieram através das máquinas e demais mercadorias que tinha no anterior estabelecimento, e também, com 2 terrenos na capital (Rua do Triunfo e Rua dos Gusmões, na freguesia de Santa Ifigênia). Dessa forma, a J. Arbenz \& Cia. corrobora as indicativas de Dean (1971) e Marson (2012) sobre a matriz dupla da burguesia industrial paulista, bem como de suas diferenciadas funções nestas

(7) Devemos ressaltar que estas oficinas e fundições se abasteciam de matérias-primas importadas, posto que, no período 1882-1887, entre as mercadorias importadas de forma direta pelo estrangeiro através de porto de Santos, a principal rubrica foi ferro, aço em vergas e lâminas, resultado da incipiente produção interna destes materiais (Relatório São Paulo, 1887, p. 132, 261 262; Suzigan, 2000, p. 248).

(8) Joaquim Franco de Camargo Junior era um dos principais proprietários agrícolas do município de Araras na segunda metade do XIX. Vinculado à família Lacerda Franco, ele também era um dos sócios da casa comissária e exportadora J. F. de Lacerda \& Cia., empresa com sede em Santos (SP) e filiais na cidade do Rio de Janeiro e em Havre (França), que foi a maior firma exportadora de café no porto santista entre 1885-1887 (Silva, 2015).

(9) Para esta e as demais conversões dos valores em mil-réis para libras esterlinas foi utilizado índice de preços para o Reino Unido, ano base 1913 = 100, disponível em Mitchell (2007, p. 955). 
empresas: ao imigrante caberia a responsabilidade técnica administrativa - tanto que a gerência da firma ficava a cargo de Arbenz - e ao fazendeiro a possibilidade de financiar o empreendimento e diversificar suas fontes de acumulação (Contrato J. Arbenz \& Cia., 5 fev. 1884).

A 17 de fevereiro daquele ano, aparecia um grande anúncio no Correio Paulistano com o título "Indústria Nacional", que descrevia as instalações da J. Arbenz \& Cia. na capital paulista - localizadas na Rua da Estação, 22 -, uma grande oficina de caldeiraria de cobre, ferro e fundição de bronze. Os produtos por ela ofertados eram: armações de máquinas para qualquer indústria, ferramentas para maquinistas, ferreiros, serralheiros e funileiros; construção de aparelhos para retificação e destilação de aguardente, aparelhos para engenhos centrais e fábricas de açúcar, caldeiras de cobre ou de ferro de qualquer forma, encanamentos de cobre ou de ferro para vapor ou água; instalação de para-raios, conforme demandado por empresas de seguro europeias. Além de construtora, a empresa era importadora de equipamentos como: rodas hidráulicas, máquinas a vapor, turbinas e outras, indicando ainda que a J. Arbenz \& Cia. cuidaria da instalação destes maquinários importados (Correio Paulistano, 17 fev. 1884, p. 4).

No final daquele ano, a 23 de novembro de 1884, em novo anúncio no Correio Paulistano evidenciava-se a origem do equipamento importado que foi referido acima. A J. Arbenz \& Cia. indicava ser o único importador de máquinas a vapor construídas pela firma inglesa Robey \& Co. Esta empresa da cidade britânica de Lincoln - que apresentara seus inventos na Exposição Universal de Viena em 1873 - exportava ao Brasil as turbinas, rodas e motores que se destinavam às firmas industriais e, principalmente, ao maquinário que passou a ser encontrado nos engenhos de beneficiamento de café das maiores fazendas do Oeste Paulista nas décadas de 1870 e 1880: ventiladores, descascadores, separadores, catadores e estufas de seca (Correio Paulistano, 23 nov. 1884, p. 3; Argolo, 2004, p. 78-79; Sacheri, 1874, p. 25).

A presença de máquinas de beneficiamento das firmas campineiras indicava a evolução técnica e produtiva do complexo econômico paulista, que dobrou o número de cafeeiros entre 1876-1883, oferta do produto que se aproveitaria de um novo ciclo ascendente dos preços no mercado internacional a partir de 1886 (Cano, 1981, p. 35; Delfim Netto, 2009). De outra parte, como demonstraram Dean (1971) e Marson (2012), este maquinário expunha uma acirrada competição no surgimento do setor de bens de capital paulista, disputa que apresentava similaridades: empresas formadas por imigrantes surgiram como importadoras - a firma Arens Irmãos (Jundiaí-SP) era o único agente da fábrica inglesa de máquinas a vapor Marshall Sons \& Co. - que, com o tempo, tornaram-se produtoras de máquinas no território nacional. No caso da firma inglesa Robey \& Co., suas máquinas eram vendidas na capital paulista em 1880 pela casa Moreira Pinho \& Cia. e, entre 1881-1883, com exclusividade pela casa Heyland \& Cia., até que, em 1884, esta representação passou a J. Arbenz \& Cia. (Correio Paulistano, 18801883). 


\section{Lacerda, Camargo \& Arbenz (1885-1886): a ampliação do investimento para se manter no setor de bens de capital paulista}

Na década de 1880, o setor de bens de capital (empresas de máquinas, oficinas mecânicas e fundições) da província de São Paulo passava por um processo de aumento da concorrência, da complexidade das empresas e de deslocamento regional. Em 1873, havia 15 empresas no setor, concentradas em reparar máquinas e fazer equipamentos mais simples profissionais como torneiros, carpinteiros, ferreiros, marceneiros, maquinistas - sendo que estas firmas se localizavam majoritariamente no interior paulista - apenas a Haupt \& Cia. e a George Hunde. Mas, em 1891, consoante à liderança que São Paulo atingiria na produção cafeeira do Brasil e seus efeitos na demanda por máquinas e equipamentos agrícolas, o setor passaria a ser formado por 23 empresas, com 11 destas tendo oficinas na cidade de São Paulo e 6 no município de Campinas. Ademais, as maiores empresas do setor agregaram a função de elaboradores de máquinas - Mc Hardy \& Cia., Lidgerwood \& Cia. e Arens Irmãos - tornandose "importadores e fabricantes" de manufaturas que concorriam com bens estrangeiros (Marson, 2012, p. 495-500; Suzigan, 2000, p. 249) ${ }^{10}$.

A partir do empuxo vindo da expansão cafeeira, as oportunidades de expansão no setor de máquinas e equipamentos paulista estavam abertas aos empresários com capacidade de financiarem os investimentos necessários à formação de firmas que pudessem competir com as grandes importadoras-produtoras de máquinas, o que podia ser feito, por exemplo, com o aumento do capital de firmas já existentes.

Com vistas à maior participação no setor de bens de capital paulista, no dia 6 de agosto de 1885, na cidade de São Paulo, ficava dissolvida a J. Arbenz \& Cia. e, em seu lugar, seria formada a sociedade solidária Lacerda, Camargo \& Arbenz, que assumiria todos os negócios da empresa na praça comercial da capital. Esta sociedade era formada pelos antigos integrantes da firma dissolvida, Joaquim Franco de Camargo Junior e João Arbenz e, também, por Candido Franco de Lacerda, que era sobrinho de Joaquim e importante fazendeiro na cidade de São Carlos (SP) ${ }^{11}$. O capital da empresa era de 300 contos de réis (23.250 libras esterlinas), valor que era mais de sete vezes o capital da sociedade extinta, indicando uma maior capacidade de competição da empresa no setor. Este capital seria constituído pelos 130 contos de Joaquim Franco e a mesma quantia de Candido Franco de Lacerda, e por 40 contos de João Arbenz. Os eventuais lucros da empresa, deduzidos $10 \%$ para o Fundo de Reserva, seriam divididos na proporção dos capitais de cada sócio na firma. Ademais, a gerência da sociedade saía das mãos do suíço Arbenz e ficava, em primeiro lugar, para Joaquim Franco e, caso ele não pudesse,

(10) Uma das firmas que se tornou produtora de máquinas agrícolas é a Guilherme Mc Hardy \& Cia., localizada em Campinas. Em uma propaganda do ano de 1884, a empresa indicava como sua especialidade a produção das máquinas de beneficiar café com sistema Mc Hardy, produzidas em suas oficinas próprias. Como prova da eficiência reconhecida do equipamento, a empresa destacava que já havia vendido mais de mil máquinas até aquele momento (Correio Paulistano, 5 jun. 1884, p. 4).

(11) Cândido Franco de Lacerda era filho de José de Lacerda Guimarães - o Barão de Arary - de quem recebeu terras no município de São Carlos que constituíam a Fazenda Paraizo. A propriedade serviu de base para que, junto de seus irmãos Antonio e José Franco de Lacerda, fosse criada a Lacerda \& Irmãos em 1874, uma sociedade agrícola com capital de 200 contos de réis e destinada ao plantio e venda de café (Silva, 2015, p. 363). 
seria substituído por Cândido Lacerda (Contrato Lacerda, Camargo \& Arbenz, 3 set. 1885; Correio Paulistano, 9 ago. 1885, p. 3).

Após a majoração de seu capital, a Lacerda, Camargo \& Arbenz passou a anunciar a busca por trabalhadores destinados a expandir a produção de suas instalações na cidade de São Paulo (grande oficina mecânica, fundição e caldeiraria de cobre e ferro na Rua do Triunfo, 39): torneiros, modeladores, marceneiros e caldeireiros de cobre. Pela primeira vez, a empresa constava como uma das fornecedoras da Prefeitura Municipal da cidade de São Paulo que, na sessão ordinária de 28 de abril de 1886, determinava o pagamento de 384 mil réis referentes à elaboração de 10 bancos de jardim (Correio Paulistano, 11 mar. 1886, p. 3; 1 maio 1886, p. 3).

Atestando esta evolução, as instalações da firma foram escolhidas pela firma Engelberg, Siciliano \& Cia. para uma demonstração - entre os dias 19 a 22 de junho de 1886 - de máquinas das quais eles eram inventores e fabricantes na cidade de Piracicaba: máquina de beneficiar arroz "Evaristo Conrado" e o descascador de café "Engelberg", aparelhos inventados por estes imigrantes alemães e que, segundo anunciado pelo jornal, tornavam-se conhecidos na Europa, América e Índia Oriental (Correio Paulistano, 18/06/1886) ${ }^{12}$. Ademais, as oficinas receberam a visita do imperador D. Pedro II - acompanhado do ministro da Fazenda (Francisco Belisário Soares de Sousa), da Agricultura (Antonio da Silva Prado) e do presidente da província de São Paulo (Antonio de Queirós Teles) - que visitou também a oficina de Adolph Sydow e Elias Pacheco e Chaves, também na capital paulista (Correio Paulistano, 22 out. 1886, p. 2)

As maiores firmas do setor de bens de capital paulista no final dos anos 1880 eram as que se anunciavam como "fabricantes e importadores", posto que, isto significava que elas haviam deixado a condição de meras reparadoras de maquinário importado para se consolidarem como fabricantes de equipamentos agrícolas - caso da Lidgerwood \& Cia., Mc Hardy \& Cia., Arens Irmãos e da própria Engelberg, Siciliano \& Cia ${ }^{13}$. A Lacerda, Camargo \& Arbenz atingira esta condição em 1886, quando se anunciava como fabricante e importadora, neste caso, das máquinas inglesas da Robey \& Co.: máquinas a vapor (locomóveis e fixas), turbinas, rodas e motores de ferro batido. Constata-se que estas maiores empresas do setor

(12) Em dezembro de 1884, o alemão João Conrado Engelberg, residente na cidade de Piracicaba, e seus filhos Evaristo, Pedro e Alípio - estes brasileiros e todos mecânicos - receberam duas patentes pelos seus inventos: a de n. 191 referida ao descascador de arroz "Evaristo Conrado" e, outra, n. 192, referente ao ventilador de café em coco "Apartador de Pedras". No ano seguinte, em abril de 1885, eles se juntaram aos irmãos Francisco e Alexandre Siciliano, que eram comerciantes italianos também estabelecidos em Piracicaba, para a formação da Engelberg, Siciliano \& Cia., sociedade destinada à fabricação e comércio de máquinas voltadas à lavoura e indústria, cujo capital era de 32 contos de réis (2.747 libras esterlinas) (Correio Paulistano, 20 dez. 1884 , p. 1; 21 abr. 1885, p. 3).

(13) A denominação destas maiores firmas como "fabricantes e importadores" é também reflexo da questão tarifária no final do Império, pois o Decreto n. 8360 de 31 de dezembro de 1881 diminuiu a taxação sobre as matérias-primas (ferro e aço), contudo, não eliminou as isenções de direitos de importação sobre máquinas e equipamentos, induzindo estas grandes empresas a reunirem estas duas funções (Suzigan, 2000, p. 248). 
aglutinavam tanto a importação de maquinário quanto a fabricação própria em suas oficinas, como proposto por Dean (1971, p. 38) e Marson (2012, p. 38) ${ }^{14}$.

O ano de 1886 marcou a consolidação da Lacerda, Camargo \& Arbenz como um dos mais relevantes agentes do setor de máquinas e equipamentos na província de São Paulo. Ademais, a empresa representava a união de imigrantes e fazendeiros neste início do crescimento industrial paulista. Todavia, esta aliança seria desfeita rapidamente, fato que não impediria a evolução e expansão da empresa.

\section{Lacerda, Camargo \& Cia. (1886-1890): o grande capital cafeeiro e sua atuação industrial}

Em que pese, a posição de destaque alcançada pela empresa no rol das firmas de bens de capital da província de São Paulo na década de 1880, a sociedade formada pelos Lacerda Franco e o suíço Arbenz não se manteve por muito tempo.

No dia 18 de setembro de 1886, na capital paulista, foi registrado o distrato da Lacerda, Camargo \& Arbenz em virtude da desistência de João Arbenz em se manter na sociedade. De sua parte, ele receberia uma indenização de 16 contos de réis pelo capital integralizado até aquele momento na finda empresa, sob a condição de finalizar todas as obras recebidas em encomendas de caldeiraria de cobre, responsabilizando-se por todos os trabalhos e ficando encarregado também de fazer os assentamentos. Já os Lacerda Franco - Cândido e Joaquim seriam os únicos sócios da empresa Lacerda, Camargo \& Cia. que, a 22 de novembro de 1886, anunciavam à praça comercial paulista que assumiram todo o ativo e passivo da antiga firma (Desistência João Arbenz, 18 set. 1886; Correio Paulistano, 24 nov. 1886, p. 3$)^{15}$.

A Lacerda, Camargo \& Cia. continuou na operação dos negócios industriais na economia paulista. A empresa constava no passivo da Cia. Carris de Ferro de São Paulo para o ano de 1886 - com um valor de 2 contos e 800 mil réis -, uma grande demandante de bens industriais por ser a principal empresa no transporte urbano da capital que operava o sistema de bondes puxados por mulas. Ao mesmo tempo, ela mantinha-se como prestadora de serviços à Prefeitura Paulistana, neste caso, recebendo o valor de 6 contos e 500 mil réis pelas obras do gradil do jardim do Largo de São Bento. Ademais, a empresa também recebia por serviços prestados à Província, somando o valor de 1 conto de réis entre maio e junho de 1887 que lhe

(14) Em anúncio de maio de 1886, a Lacerda, Camargo \& Arbenz expunha toda a gama de suas atividades. Dava orçamento para fornecer todo o material fixo e rodante para ferrovias, bondes; engenhos centrais, serrarias e pontes. Possuía máquinas para trabalhar ferro (tornos), madeira (serras); engenhos de cana e engrenagens para moinhos superiores; alambiques simples (como os retificadores e encanamentos); bombas hidráulicas (para incêndio, jardins e poços); tubos de ferro, cobre, latão, chumbo e borracha; torneiras, válvulas e registros; para-raios; ferramentas para ferreiros, eixos patentes, arrebites, porcas e parafusos. Além disso, lastreada pelos seus agentes em Londres, dizia ser capaz de importar todo tipo de maquinário com a cobrança de comissão (Correio Paulistano, 18 maio 1886, p. 3).

(15) As pesquisas não nos dão uma razão clara para a desistência de João Arbenz. Aventamos o desejo do suíço em ter o total controle da empresa, pois ele não era mais o gerente da casa, função exercida pelos Lacerda Franco. Esta vontade se realizou em fevereiro de 1887, quando ele anunciava à praça a formação da A. W. Arbenz \& Cia., uma nova caldeiraria na capital paulista por ele comandada (Correio Paulistano, 4 fev. 1887, p. 4). 
foi pago pelo Tesouro Provincial (Correio Paulistano, 3 mar. 1887, p. 4; 11 mar. 1887, p. 3; 14 maio 1887, p. 3; 1 jun. 1887, p. 3; Carone, 2001, p. 60).

Em julho de 1887, a Lacerda, Camargo \& Cia. adquiriu a configuração societária que não se alteraria até a incorporação da empresa pela CMISP em 1890. Ao sócio Candido e Joaquim Franco uniu-se José de Lacerda Guimarães (Barão de Arary), fazendeiro da cidade paulista de Araras que era pai do primeiro e cunhado do segundo ${ }^{16}$. Esta sociedade comanditária tinha um capital de 500 contos de réis - equivalente a 54.901 libras esterlinas, mais de duas vezes o capital da firma anterior - formado da seguinte maneira: os 200 contos de réis dos sócios comanditados Joaquim Franco de Camargo Junior e Candido Franco de Lacerda, respectivamente, dos quais 165 contos provenientes de seus capitais e lucros da extinta firma Lacerda, Camargo \& Arbenz, e mais 35 contos em moeda corrente; e do sócio comanditário José de Lacerda Guimarães 100 contos, dos quais 30 contos referentes ao valor do terreno que comprara do Dr. Elias Antonio Pacheco e Chaves na cidade de São Paulo, e 70 contos de réis em moeda corrente (Contrato Lacerda, Camargo \& Cia., São Paulo, 11 jun. $1887)^{17}$.

O objetivo da empresa continuava a ser o comércio de importação, exportação e fabrico de máquinas, aparelhos, instrumentos e materiais para todas as indústrias, e para qualquer outro ramo de negócio que convier. Para tanto, os gerentes Candido e Joaquim Franco valeram-se do cabedal familiar dos Lacerda Franco para contribuir à duplicação do capital social de sua firma manufatureira, sendo que, além de fazendeiros, o Barão de Arary e Joaquim Franco eram sócios da maior casa exportadora de café em Santos (SP) entre 1885-1887, a J. F. de Lacerda \& Cia ${ }^{18}$. Neste sentido, o ingresso do Barão de Arary ao lado de seu cunhado Joaquim Franco nesta firma industrial era indicativo destes dois agentes como membros do grande capital cafeeiro paulista, ou seja, indivíduos que não se restringiram à lavoura na busca pela acumulação e, portanto, tornaram-se nomes comuns em outras empresas deste complexo econômico, atuando como sócios e/ou acionistas de ferrovias, casas de importação e exportação, bancos, empresas de serviços públicos e indústrias, como aponta Perissinotto (1994, p. 49), Silva (1995, p. 54), Mello (2009, p. 115) e Saes (2002, p. 187).

(16) Na lista dos votantes de Araras em 1876, José de Lacerda Guimarães era classificado como fazendeiro e, com uma renda de 20 contos de réis, estava entre os três indivíduos mais ricos da localidade 1876. Em 1897, quando morreu o Barão de Arary, seu inventário mostra que a fazenda Montevidéo possuía uma área total de 827,5 alqueires, sendo 270 alqueires ocupados pelos cafezais, 27,07 alqueires em matas próprias para café, 339 alqueires de terras baixas para mantimentos, 48,08 alqueires de terras ordinárias, 138 alqueires ocupados pelos pastos e fechos, e 4 alqueires ocupados pelas benfeitorias. Somados os valores da fazenda, suas benfeitorias, cafezais e animais, eles totalizaram 1.817 contos de réis, o equivalente a $31 \%$ de sua riqueza bruta (Inventário Barão de Arary, 1897; Votantes, 1876).

(17) Elias Antonio Pacheco e Chaves era um importante fazendeiro, empresário e político paulista - ligado à família Prado - que, inclusive, havia sido presidente da província de São Paulo nos anos de 1885 e 1886.

(18) A casa comissária e exportadora J. F. de Lacerda \& Cia. tinha como sócios os membros da família Lacerda Franco: Antonio de Lacerda Franco, Joaquim Franco de Lacerda, José de Lacerda Guimarães (Barão de Arary), Joaquim Franco de Camargo Junior e João Soares do Amaral (casado com a filha do Barão de Arary). A empresa tinha sede em Santos e filiais no Rio de Janeiro e na cidade portuária francesa do Havre. O feito de ter se tornado a maior firma exportadora do café pelo porto de Santos, entre 1885-1887, deve ser realçado pelo fato das outras nove maiores congêneres serem firmas estrangeiras, como a alemã Theodor Wille \& Co. (Contrato J. F. de Lacerda \& Cia., 1884). 
Tabela 1

Balanço Patrimonial da Lacerda, Camargo \& Cia, 31 de dezembro de 1887 - valores em contos de réis correntes

\begin{tabular}{|c|c|c|c|}
\hline ATIVO & $\begin{array}{l}\text { Contos } \\
\text { de Réis }\end{array}$ & PASSIVO & $\begin{array}{l}\text { Contos } \\
\text { de Réis }\end{array}$ \\
\hline Ativo Circulante (AC) & 643 & Passivo Circulante (PC) & 655 \\
\hline Caixa & 2 & Barão de Arary (conta geral) & 20 \\
\hline Devedores diversos & 233 & Barão de Arary (conta de empréstimos) & 108 \\
\hline Nielsen \& C. (letras caucionadas) & 130 & Barão de Arary (conta especial) & 70 \\
\hline Nielsen \& C. (conta especial) & 4 & $\begin{array}{l}\text { Joaquim Franco de Camargo Junior (conta } \\
\text { geral) }\end{array}$ & 7 \\
\hline London and Brazilian Bank Ltda. & 3 & $\begin{array}{l}\text { Joaquim Franco de Camargo Junior (conta } \\
\text { de empréstimo) }\end{array}$ & 13 \\
\hline Letras a receber & 44 & Nielsen \& C. (conta geral São Paulo) & 97 \\
\hline Estoque de mercadorias nos armazéns & 201 & Banco Mercantil de Santos (São Paulo) & 16 \\
\hline $\begin{array}{l}\text { Conta de Fabricação (material e mão-de- } \\
\text { obra) }\end{array}$ & 19 & C. de Murrieta \& C. (banco de Londres) & 77 \\
\hline $\begin{array}{l}\text { Conta do Fabrico da Fundição (ferro e } \\
\text { bronze existente) }\end{array}$ & 7 & $\begin{array}{l}\text { Conta garantida de Robey \& C. (empresa } \\
\text { inglesa de máquinas agrícolas) }\end{array}$ & 47 \\
\hline Ativo Permanente (AP) & 523 & Letras caucionadas & 130 \\
\hline Capital a realizar & 215 & Letras a pagar & 40 \\
\hline $\begin{array}{l}\text { Custeio da Fábrica (terrenos, edifícios, } \\
\text { máquinas e armações das oficinas, modelos } \\
\text { de madeira, modelos de ferro e bronze, } \\
\text { caixas de ferro para a fundição) }\end{array}$ & 238 & Credores diversos & 30 \\
\hline Terreno do Bom Retiro & 30 & Patrimônio Líquido (PL) & 514 \\
\hline Terreno e prédio no Brás & 31 & Capital & 500 \\
\hline Utensílios (escritório e sala de desenho) & 3 & Fundo de reserva & 14 \\
\hline Carretões & 3 & Passivo Total (PT) & 1.169 \\
\hline $\begin{array}{l}\text { Ações da Cia. Carris de Ferro de Santo } \\
\text { Amaro }\end{array}$ & 3 & & \\
\hline Ativo Total (AT) & 1.166 & & \\
\hline \multicolumn{4}{|l|}{ Indicadores Financeiros } \\
\hline Liquidez Corrente (AC/PC) & 0,982 & & \\
\hline $\begin{array}{l}\text { Liquidez Geral (Quociente Cobertura Total) } \\
\text { (AT/PC) }\end{array}$ & 1,78 & & \\
\hline Imobilização do Capital (AP/PL) & 1,017 & & \\
\hline Quociente Rentabilidade Patrimônio Líquido & 0,132 & & \\
\hline Quociente Rentabilidade Ativo & 0,058 & & \\
\hline $\begin{array}{l}\text { Estrutura Capital: Participação Capital } \\
\text { Terceiros }\end{array}$ & 1,274 & & \\
\hline $\begin{array}{l}\text { \% Capital de Terceiros no Ativo Total } \\
\text { (PC/AT) }\end{array}$ & 0,56 & & \\
\hline \% Capital Próprio no Ativo Total (PL/AT) & 0,44 & & \\
\hline
\end{tabular}

Fonte: Balanço Lacerda, Camargo \& Cia., 31 dez. 1887.

Obs.: ao final do Balanço está descrito o valor do lucro líquido da empresa no ano de 1887, que foi de Rs. 68:334\$409 (valor arredondado de 68 contos de réis). A partir desta informação foi possível calcular o Quociente de Rentabilidade do Patrimônio Líquido (Lucro Líquido/Patrimônio Líquido) e do Ativo (Lucro Líquido/Ativo Total). 
A Tabela 1 permite-nos confrontar a condição financeira da Lacerda, Camargo \& Cia. com alguns apontamentos feitos pela historiografia sobre o início da indústria paulista ${ }^{19}$. Primeiro, os indicadores financeiros demonstram uma boa condição de solvência da empresa, considerando tanto curto prazo - dado pela Liquidez Corrente ${ }^{20}$ de 0,982 - e, sobretudo, a longo prazo, observado o Quociente de Cobertura Total ${ }^{21}$ no valor de 1,78, ou seja, havia quase 2 unidades monetárias de ativo para cada um dos passivos da empresa. Ademais, o valor de 1,017 de Imobilização do Capital ${ }^{22}$ aponta para o relevante peso das instalações e do maquinário, bem como dos terrenos pertencentes à firma.

A empresa, além da robusta solvência, auferiu uma importante lucratividade no ano de 1887, constatada pelo Quociente de Rentabilidade do Patrimônio Líquido ${ }^{23}$ e do Ativo ${ }^{24}$, com valores de $13,2 \%$ e 5,8\%, respectivamente ${ }^{25}$. Estes lucros podem ser entendidos como indutores do investimento de membros do grande capital cafeeiro - neste caso, da família Lacerda Franco - valendo-se do crescimento do setor de bens de capital a reboque da expansão dos cafezais paulistas, como aponta Suzigan (2000). Mas, sobretudo, os representantes do grande capital cafeeiro encontravam nas firmas industriais mais uma forma de diversificação de suas fontes de acumulação, fazendo do setor manufatureiro uma alternativa às eventuais agruras da lavoura resultantes de suas flutuações produtivas, como indicado por Cano (1981), Mello (2009), Saes (2002), além do próprio Dean (1971).

Ademais, a Tabela 1 traz no passivo circulante informações sobre as fontes de financiamento à Lacerda, Camargo \& Cia. Segundo o indicador da estrutura do capital, para cada unidade monetária investida de capital próprio haveria 1,274 unidades de capitais de terceiros, indicador corroborado pelo 56\% de Capitais de Terceiros no Ativo Total. Porém, ao

(19) Devemos indicar a dificuldade em encontrar balanços patrimoniais de empresas paulistas antes de 1890 - que poderiam ser comparados ao da Lacerda, Camargo \& Cia. - posto que, apenas com as reformas institucionais na Lei das Sociedades Anônimas em 1890 é que seria colocada a necessidade de as empresas aprovarem e publicarem suas demonstrações financeiras (Levy, 1994, p. 178).

(20) O índice de liquidez corrente demonstra quantas unidades monetárias a empresa possui, em disponibilidades ou realizáveis em curto prazo, para cada unidade monetária de dívida de curto prazo; resultado maior que 1 indica boa condição de liquidez da empresa frente às suas dívidas.

(21) O quociente de cobertura total é dado pela razão do ativo total dividido pelo passivo circulante. Indica a possibilidade de a empresa cumprir seus compromissos financeiros ao mostrar quantas unidades monetárias de ativos reais existem para pagamentos frente a cada unidade monetária de dívida.

(22) O quociente de imobilização do capital é dado pela razão do ativo permanente pelo patrimônio líquido. O quociente de imobilização indica a proporção do capital (patrimônio líquido) imobilizado em ativo fixo (ativo permanente).

(23) O quociente de rentabilidade do patrimônio líquido é dado pela razão dos lucros que passam para o próximo ano (conta lucros e perdas acrescida dos lucros suspensos) pelo patrimônio líquido. Ele revela qual foi a taxa de rentabilidade obtida pelo capital próprio investido na empresa, ou seja, quanto a empresa ganhou de lucro líquido para cada unidade monetária de capital próprio investido.

(24) O quociente de rentabilidade do ativo é dado pela razão dos lucros que passam para o próximo ano (conta lucros e perdas acrescida dos lucros suspensos) pelo ativo total. O indicador demonstra o potencial de geração de lucros por parte da empresa, isto é, quanto a empresa obteve de lucro líquido para cada unidade monetária de investimento totais.

(25) A título de comparação, para fomentar o investimento em ferrovias na segunda metade do XIX foi adotado o sistema de garantia de juros que assegurava uma remuneração ao capital alocado nas estradas de ferro de 7\% (Saes, 2002, p. 178). 
detalharmos as contas do passivo circulante constatamos que três delas referem-se ao Barão de Arary e duas ao sócio Joaquim Franco de Camargo Junior que, somadas, atingem o valor de 218 contos de réis, representando 33\% do passivo circulante. Dessa forma, a Lacerda, Camargo \& Cia., que não era uma sociedade por ações, dependia, em boa medida, do financiamento levantado pela rede dos Lacerda Franco, traço característico de empresas familiares (Penrose, 2006, p. 73).

Às fontes familiares de financiamento somavam-se as institucionais, neste caso, sendo tanto nacionais quanto estrangeiras. Apesar das dificuldades arroladas pela historiografia acerca da escassez do crédito industrial ${ }^{26}, 37 \%$ do financiamento da empresa vinha de bancos nacionais - Nielsen \& C. (que se transformaria no Banco do Comércio e Indústria de São Paulo) e Banco Mercantil de Santos - o que se explicava pela preferência destas instituições emprestarem aos membros do grande capital cafeeiro que, usualmente, eram seus acionistas e diretore ${ }^{27}$. Ademais, havia o bom trânsito que estes agentes do café tinham junto aos bancos, considerando a relevância da casa exportadora J. F. de Lacerda \& Cia. na metade dos anos 1880 (Saes, 1986, p. 80; Silva, 2015, p. 561).

Sobre as fontes de crédito estrangeiras, que somaram $19 \%$ do passivo circulante, encontramos as contas C. de Murrieta \& C. e conta garantida de Robey \& C., ambas empresas inglesas. A presença da empresa de máquinas Robey \& C. tratava-se do financiamento do fornecedor britânico a um de seus compradores de materiais, sendo que o relacionamento entre a firma inglesa e a fundição paulista vinha desde 1884, quando ainda estava sob a razão social de J. Arbenz \& Cia. Em relação à C. de Murrieta, esta empresa era um banco formado em Londres na metade do século XIX pelo espanhol Cristóbal de Murrieta, que antes havia sido um importante comerciante no México e imigrara à Inglaterra nos anos 1820, constituindo o banco e tendo como foco o financiamento de empresas latino-americanas (Gila e Urquijo, 2002, p. 251-253). Tanto em relação ao banco quanto à fabricante de máquinas britânica, o caso da Lacerda, Camargo \& Cia. corrobora o exposto por Dean (1971) e Marson (2012 e 2015) sobre a facilidade no acesso ao crédito das empresas estrangeiras por parte das firmas industriais paulistas criadas por imigrantes - neste ponto, o suíço João Arbenz - e como este crédito mais farto viabilizava a aquisição máquinas e matérias-primas vindas do exterior.

(26) As dificuldades na obtenção de crédito de longo à prazo indústria junto aos bancos, principalmente antes de 1890, é destacada, por exemplo, em Versiani e Suzigan (2000), Saes (1986) e Carone (2001).

(27) Inicialmente, foram somados os valores das seguintes contas do Passivo Circulante: Nielsen \& C. (conta geral São Paulo) valor de 97 contos de réis, Banco Mercantil de Santos (São Paulo) valor de 16 contos de réis, Letras Caucionadas - que como demonstra o Ativo estavam vinculadas ao banco Nielsen \& C. - no valor de 130 contos de réis que, ao todo, correspondem a 243 contos de réis, montante que representa $37 \%$ do valor do Passivo Circulante (655 contos de réis). 
Tabela 2

Demonstração de Lucros e Perdas da Lacerda, Camargo \& Cia., 31 de dezembro de 1889 valores em contos de réis correntes

\begin{tabular}{|c|c|c|c|}
\hline Débito & $\begin{array}{l}\text { Contos de } \\
\text { Réis }\end{array}$ & Crédito & $\begin{array}{c}\text { Contos de } \\
\text { Réis }\end{array}$ \\
\hline $\begin{array}{l}\text { Dívidas duvidosas (saldo de diversas contas } \\
\text { que consideramos perdidas) }\end{array}$ & 2 & $\begin{array}{l}\text { Terrenos do Bom Retiro (pelo lucro } \\
\text { líquido na venda de metade de nossos } \\
\text { terrenos) }\end{array}$ & 36 \\
\hline $\begin{array}{l}\text { Devedores e credores gerais (saldo de } \\
\text { diversas contas que consideramos perdidas) }\end{array}$ & 4 & Fazendas Gerais & 62 \\
\hline $\begin{array}{l}\text { Dívidas duvidosas (dedução que fizemos nos } \\
\text { débitos de diversos devedores pelo valor que } \\
\text { ainda julgamos cobrável) }\end{array}$ & 9 & Conta de Fabricação & 23 \\
\hline $\begin{array}{l}\text { Móveis e armação da Rua da Quitanda n. } 1 \\
\text { (depreciação de } 10 \% \text { sobre seu valor de Rs. } \\
\text { 7:299\$080) }\end{array}$ & 1 & Conta do Fabrico da Fundição & 1 \\
\hline Total & 16 & Total & 122 \\
\hline Lucro Líquido & & & 106 \\
\hline \multicolumn{4}{|c|}{ Lucro que se distribui da seguinte forma } \\
\hline $\begin{array}{l}\text { Fundo de Reserva ( } 10 \% \text { sobre o lucro } \\
\text { líquido) }\end{array}$ & 11 & $\begin{array}{l}\text { Candido Franco de Lacerda (sua parte } \\
\text { do lucro de } 20 \% \text { sobre Rs. } \\
\text { 132: } 707 \$ 880 \text { de seu Capital } \\
\text { realizado) }\end{array}$ & 26 \\
\hline $\begin{array}{l}\text { Quantia creditada ao Fundo de Reserva para } \\
\text { fazer face a qualquer prejuízo inesperado }\end{array}$ & 15 & $\begin{array}{l}\text { Barão de Arary (sua parte do lucro de } \\
20 \% \text { sobre Rs. 100:000\$000 de seu } \\
\text { Capital - } 20 \text { contos - menos quantia } \\
\text { que creditamos à sua conta corrente, } \\
\text { sendo excesso de seu capital } \\
\text { realizado) }\end{array}$ & 11 \\
\hline $\begin{array}{l}\text { Devedores e credores gerais (quantia retida } \\
\text { para gratificações aos empregados) }\end{array}$ & 5 & $\begin{array}{l}\text { Devedores e credores gerais (Barão } \\
\text { de Arary; excesso de seu capital } \\
\text { realizado) }\end{array}$ & 9 \\
\hline $\begin{array}{l}\text { Joaquim Franco de Camargo Junior (sua } \\
\text { parte do lucro de } 20 \% \text { sobre Rs. } \\
\text { 149:357 } \$ 880 \text { de seu Capital realizado) }\end{array}$ & 30 & & \\
\hline
\end{tabular}

Fonte: DLP Lacerda, Camargo \& Cia., 31 dez. 1889.

A Tabela 2, com a Declaração de Lucros e Perdas da Lacerda, Camargo \& Cia. para o ano de 1889, indica um lucro líquido da empresa no valor de 106 contos de réis que foi distribuído aos três sócios de acordo com suas respectivas partes no capital já integralizado à empresa, uma vez deduzidas as parcelas para gratificações aos empregados e o fundo de reserva.

O lucro líquido de 106 contos de réis - equivalente a 13.101 libras esterlinas representava um valor $75 \%$ maior que o auferido pela Lacerda, Camargo \& Cia. em 1887. As 
Receitas, por sua vez, vinham da venda de máquinas e equipamentos a particulares e, como demonstrado anteriormente, dos serviços prestados à prefeitura paulistana, a algumas do interior e ao governo estadual. Sobre este último ponto, em março de 1890, a fundição dos Lacerda Franco arrematou o contrato para o abastecimento de água da cidade de Amparo, concessão que se estenderia por 32 anos. Ademais, a empresa tinha contratos com o Governo Estadual para a elaboração de pontes na própria cidade de Amparo e na Serra da Bocaina (Rio Paraíba do Sul) (Correio Paulistano, 27 mar. 1890, p. 1; 26 abr. 1890, p. 1; 24 maio 1890, p. 2$)^{28}$.

No primeiro semestre de 1890 constata-se que a Lacerda, Camargo \& Cia. era uma empresa que vinha de um ano lucrativo e com serviços cada vez maiores e mais complexos que, entretanto, demandavam grandes somas de capitais para sua contratação e execução. $\mathrm{O}$ cenário econômico da década que se iniciava era propício à formação de grandes empresas na forma de sociedades anônimas, ao invés de firmas restritas aos capitais familiares.

\section{Cia. Mecânica e Importadora de São Paulo (1890-1892): fazendeiros e imigrantes na maior empresa de bens de capital paulista}

Em janeiro de 1890, Rui Barbosa, no cargo de ministro da Fazenda do primeiro governo republicano, encetou uma guinada na política monetária e na regulação do mercado de capitais. No dia 17 daquele mês, o ministro instituiu a Lei Bancária, criando três novos bancos de emissão (Norte, Centro e Nordeste), que foram autorizados a emitir até 450 mil contos de réis - valor que representava mais que o dobro do papel-moeda em circulação naquele momento - em papéis que seriam inconversíveis e lastreados em apólices da dívida pública. Junto à lei bancária, Rui Barbosa instituiu os decretos n. 164 e 165, que facilitavam a formação de sociedades anônimas, pois possibilitavam a estas empresas negociar suas ações apenas com a integralização de $10 \%$ do capital subscrito pelos incorporadores - antes era necessário subscrever $20 \%$ do capital - além de estabelecer a responsabilidade limitada para os acionistas das empresas, ou seja, referente apenas ao montante que ele despendeu para a entrada na sociedade (Levy, 1994, p. 127; Franco, 1989, p. 21, Marcondes; Hanley, 2010, p. 109; Tannuri, 1981, p. 65).

Segundo Musacchio (2008, p. 449-459), estas mudanças institucionais foram importantes para atrair tanto grandes quanto pequenos acionistas - por exemplo, ao obrigarem a publicação de demonstrações financeiras das empresas - que, a partir deste momento, estavam providos de maiores informações e garantias de seus investimentos. Na cidade de São Paulo, foram constituídas ao menos 222 sociedades por ações (bancos e demais empresas) nos seis meses posteriores às medidas de 17 de janeiro de 1890, sendo que em 1887 havia apenas 30 sociedades por ações paulistas. Tamanho volume na negociação dos papéis destas novas

(28) A construção da ponte sobre o Rio Paraíba do Sul (Serra da Bocaina) pela Lacerda, Camargo \& Cia. utilizou materiais metálicos vindos da Europa que contou com isenção de fretes ferroviários concedida por parte do Ministério da Agricultura, uma vez que a ponte ligaria a Estrada de Ferro do Norte (criada por fazendeiros paulistas) à Ferrovia Dom Pedro II na altura do atual município de Cachoeira Paulista (Correio Paulistano, 29 jul. 1890, p. 1). 
empresas ensejou a formação da Bolsa de Valores de São Paulo em agosto de 1890 (Hanley, 2005, p. 87).

Haber (1998, p. 276-280) aponta que a melhor organização do mercado de capitais, a partir das mudanças institucionais no começo de 1890, gerou um movimento de conversão das empresas existentes - e das que estavam sendo criadas - em sociedades anônimas. A negociação de ações e debêntures possibilitou a estas firmas um acesso menos custoso ao financiamento de suas atividades, permitindo a aquisição de maquinário moderno que, como consequência, fez com que houvesse ganhos de produtividade. Prescindindo dos capitais familiares como forma única de acesso ao crédito, as sociedades anônimas constituíram-se como empresas maiores, mais mecanizadas e eficientes, marcando a primeira onda de avanço industrial no Brasil.

Uma das sociedades anônimas formadas neste contexto foi a Companhia Mecânica e Importadora de São Paulo (CMISP), com um capital social de 5.000 contos de réis (529.026 libras esterlinas) dividido em 40 mil ações no valor de 125 mil réis cada uma. Em anúncio de 31 de agosto de 1890, o Banco União de São Paulo ${ }^{29}$, também uma empresa surgida no mesmo ano, informava que no dia 06 de setembro próximo em seu salão seria instalada a CMISP, sendo que os subscritores deveriam realizar a $1^{\mathrm{a}}$ entrada de $10 \%$ de suas respectivas ações até dois dias antes da reunião (Correio Paulistano, 31 ago. 1890, p. 1; DOESP, 30 mar. 1892).

A CMISP surgia da incorporação de outras duas firmas produtoras de máquinas e equipamentos: a piracicabana Engelberg, Siciliano \& Cia. e a Lacerda, Camargo \& Cia. Sobre a primeira, Dean $(1971$, p. 18$)$ e Carone $(2001$, p. 131) indicam que a empresa teria sido dissolvida no final da década de 1880, quando os Engelberg decidiram vender a patente de sua máquina de beneficiar café a um grupo estadunidense. Capitalizados por esta operação e pelos lucros pretéritos da firma, acrescidos de fundos familiares, os irmãos Alexandre e Francesco Siciliano vieram para a capital paulista e participaram da formação de duas novas empresas: o banco Ítalo-Brasileiro (1890) e a CMISP $(1891)^{30}$.

Em relação à Lacerda, Camargo \& Cia. que, conforme visto pelas Tabelas 1 e 2 anteriores, era uma empresa lucrativa e com boa condição de solvência entre 1887-1889, entendemos haver questões conjunturais e estruturais que levaram seus sócios a aceitarem que a empresa fosse incorporada pela CMISP. Conjunturalmente, de acordo com a documentação

(29) O banco paulistano União de São Paulo foi criado em 31 de janeiro de 1890 por Antonio de Lacerda Franco (presidente do banco) e João Baptista de Mello Oliveira, membros do grande capital cafeeiro que tinham diversos investimentos na economia paulista, além de importante participação no Partido Republicano Paulista (PRP), características semelhantes às dos demais membros da diretoria. Era o maior banco estadual em 1892, com um ativo de 112 mil contos e, além da atuação comercial, agrícola e hipotecária, o União de São Paulo destacava-se pelos investimentos industriais (o principal foi a criação da Fábrica Têxtil Votorantim) e a faculdade de banco emissor concedida nos decretos de janeiro de 1890 (Silva; Dalla Costa, 2018, p. 325326).

(30) Alexandre Siciliano nasceu em 27 de maio de 1860 na cidade italiana de San Nicola Arcella (na região da Calábria). Em virtude das dificuldades financeiras de seu pai, Alexandre migrou para o Brasil em 1869 e se estabeleceu na cidade paulista de Piracicaba, onde residiam um tio e o irmão mais velho. Ali, ele começou a trabalhar no armazém do irmão e, em 1881, casouse com a filha do coronel João Frutuoso Coelho, um rico fazendeiro local (Dean, 1971; Carone, 2001). 
arrolada no Anexo, constatamos que o valor de venda - registrado na Conta de Liquidação datada de 31 de janeiro de 1892 (Anexo) - da SOCIEDADE DOS LACERDA FRANCO FOI ELEVADO, NO TOTAL DE 1.100 CONTOS DE RÉIS (61.277 LIBRAS ESTERLINAS), sendo que $45 \%$ deste valor refere-se ao repasse das oficinas mecânicas no Brás, fundição, armazéns e respectivos terrenos que ficariam de posse da CMISP. O restante do valor de venda, somando 608 contos de réis, aparece como crédito na Demonstração e Lucros e Perdas e possibilitou alcançar um lucro líquido de 755 contos de réis (DLP Lacerda, Camargo \& Cia, 31 jan. 1892).

Este valor, uma vez lançado no patrimônio líquido do Balanço de Liquidação da Lacerda, Camargo \& Cia., fez com que o resultado desta conta (1.300 contos de réis), bem como o do ativo total (605 contos de réis) fossem maiores que o do passivo circulante (222 contos de réis) da empresa, permitindo aos sócios Candido de Lacerda e Joaquim Franco de Camargo embolsarem 475 contos (26.461 libras esterlinas) e 442 contos de réis (24.622 libras), respectivamente. À guisa de comparação, os mesmos sócios receberam no ano de 1889, como suas partes do lucro líquido da firma naquele ano, 3.708 e 3.213 libras esterlinas - segundo a tabela 2 - a corroborar a hipótese de que o principal motivo conjuntural para que os sócios aceitassem a incorporação da empresa tenha sido os lucros a eles gerados pela venda, ao invés de uma crise de solvência ou queda nos rendimentos da firma (Balanço Lacerda, Camargo \& Cia., São Paulo, 31 jan. 1892).

Ademais, havia uma questão estrutural que era o processo de transição capitalista no Brasil, movimento acelerado após a Abolição em 1888 e que, no caso da cidade de São Paulo, tinha como uma de suas facetas a preferência cada vez maior dos indivíduos abastados em alocar sua riqueza na forma de imóveis e ações de empresas, somas que antes se imobilizavam em escravos (Mello, 1990, p. 86-90). Esta preferência denotava a ascensão do mercado de capitais paulista - com a organização da Bolsa de Valores - e de seus principais componentes, as sociedades anônimas que, com a venda de seus papéis, tornavam-se empresas robustas, mecanizadas e eficientes, quando comparadas às sociedades familiares (Musacchio, 2008; Haber, 1998; Hanley, 2005). Neste sentido, ao confrontarmos o capital da CMISP com o das empresas que foram incorporadas para sua formação, evidenciamos a grande disparidade a favor da firma recém-criada: o capital social da CMISP era de 529.026 libras esterlinas (5 mil contos de réis), enquanto o da Lacerda, Camargo \& Cia. era de 54.901 libras esterlinas (500 contos de réis) e o da Engelberg, Siciliano \& Cia. era de 2.747 libras esterlinas (32 contos de réis).

Marson (2012) pontua que as maiores firmas do setor de bens de capital paulista em 1891 reuniam duas funções simultâneas: eram fabricantes e importadores de máquinas e equipamentos, sobretudo voltados à agricultura. A CMISP se coadunava a este modelo, ao se declarar como importadora direta de máquinas para todas as indústrias - era agente das firmas britânicas Robey \& Co. e Thomas Robinson, e tinha em seus depósitos os descascadores de café Engelberg - e material fixo e rodante para ferrovias, bondes; também fornecia material para abastecimento de água, pontes de ferro, engenhos centrais, engenhos de serra, máquinas 
de beneficiar café e arroz, tecelagens, olarias, instalações para iluminação elétrica, rede telefônica e telégrafos. Suas instalações na capital paulista eram compostas de: grande fundição de ferro e bronze, oficina mecânica, caldeiraria de ferro, ferraria e estamparia (Correio Paulistano, 16 dez. 1890, p. 4).

Estas diversas atividades demonstravam a elevada capacidade produtiva e comercial da CMISP, bem como sua maior possibilidade de mobilização financeira através da venda de ações, sendo que a empresa, que começou a funcionar no dia 10 de setembro de 1890, já tinha anunciada a venda de 100 de suas ações ao público seis dias depois (Correio Paulistano, 16 set. 1890 , p. 1). A necessidade de capitalizar a empresa vinha não apenas das encomendas existentes de máquinas e equipamentos, mas, também, dos planos de expansão da companhia, como a proposta enviada ao governador de São Paulo, que era Prudente de Moraes, de compra da Real Fábrica de Ferro de Ipanema, umas das poucas siderúrgicas no Brasil à época (Correio Paulistano, 15 out. 1890, p. 1).

O Relatório da CMISP para o ano de 1891 demonstra que a empresa tinha duas bases produtivas: a cidade de São Paulo, onde se localizavam suas oficinas e fundição; e a cidade de Santos, onde foi construído um armazém para a chegada de maquinário importado e, concomitantemente, a exportação de equipamentos a outros países e demais estados brasileiros, dado que a firma tinha uma agência no Rio de Janeiro responsável por divulgar os produtos da CMISP naquele estado, em Minas Gerais e Espírito Santo. Estas operações geraram um lucro líquido de 444 contos de réis (29.962 libras esterlinas), sendo que a firma remunerou seus acionistas com um dividendo de $12 \%$ sobre o capital realizado (DOESP, 30 mar. 1892).

Tabela 3

Lista de acionistas da Cia. Mecânica e Importadora de São Paulo em 31 de dezembro de 1891

\begin{tabular}{l|c}
\hline \multicolumn{1}{c|}{ Acionistas } & Número de ações \\
\hline Herança de Martinho da Silva Prado & 2.025 \\
\hline Joaquim Franco de Camargo Junior & 1.878 \\
\hline Frederico e Souza Queiroz & 1.680 \\
\hline Barão de Arary (José de Lacerda Guimarães) & 1.500 \\
\hline Carlos de Souza Queiroz & 1.150 \\
\hline Rodrigo Monteiro de Barros & 1.040 \\
\hline Augusto de Souza Queiroz & 1.000 \\
\hline Elias Antonio Pacheco e Chaves & 920 \\
\hline Candido Franco de Lacerda & 910 \\
\hline Francisco Antonio de Souza Queiroz Netto & 690 \\
\hline Demais 53 acionistas Total & 27.207 \\
\hline \multicolumn{1}{c|}{$\quad$ T0.000 } \\
\hline
\end{tabular}

Fonte: DOESP (30 mar. 1892). 
A Tabela 3, ao exibir a lista dos maiores acionistas da CMISP em 1891, demonstra os nomes de importantes famílias paulistas: Souza Queiroz, Lacerda Franco, Pacheco e Chaves, Silva Prado e Monteiro de Barros, sendo que estes nomes também compunham a Diretoria da CMISP ${ }^{31}$. Um traço comum a elas era o fato de seus membros serem importantes fazendeiros no interior de São Paulo e, concomitantemente, participarem em outros investimentos na economia cafeeira, como sócios, diretores e mesmo presidentes de empresas ferroviárias, de serviços públicos, bancos, casas de importação-exportação e, neste caso, de uma indústria. O próprio Alexandre Siciliano, que era o diretor-gerente da CMISP, tinha uma importante base agrícola, pois sua esposa era filha de fazendeiros da região de Piracicaba.

Desta forma, constatamos que a composição acionária, daquela que seria a maior empresa de bens de capital no estado de São Paulo na Primeira República ${ }^{32}$, desnuda a simbiose entre imigrantes e fazendeiros que, de uma parte, delegava o papel dinâmico desta relação aos estrangeiros, com seus conhecimentos técnicos e laços com empresas e bancos internacionais e, de outro lado, tinha nos fazendeiros a função de financiadores dos empreendimentos industriais, como bem explorado sobretudo nos trabalhos de Dean (1971) e Marson (2012, 2015).

\section{Considerações finais}

Considerando o estado de São Paulo, é possível constatar uma sincronia entre o avanço da lavoura cafeeira e o espocar da indústria paulista, sobretudo a partir da década de $1880 \mathrm{em}$ diante. Uma das expressões de tal sincronia estaria na formação do setor de bens de capital (empresas de máquinas e equipamentos, oficinas mecânicas e fundições), em que empresas surgiram para atender à demanda dos cafezais, por exemplo, desenvolvendo máquinas para beneficiar/descascar o café. A principal empresa deste setor, a partir de 1890, seria a Cia. Mecânica e Importadora de São Paulo, gerenciada pelo italiano Alexandre Siciliano e composta de vários acionistas que, originalmente, eram fazendeiros. Esta empresa surgiu da incorporação de duas firmas que já atuavam no setor - a Engelberg, Siciliano \& Cia. e a Lacerda, Camargo \& Cia. - e a análise do evolver econômico destas empresas na década de 1880 possibilitou confirmar alguns pontos já levantados pela historiografia, sendo o principal deles a simbiose entre imigrantes e fazendeiros no alvorecer da indústria no estado de São Paulo, como pontuaram Dean (1971) e Marson (2012, 2015).

(31) Os membros da Diretoria da CMISP em 1891 eram: Augusto de Souza Queiroz, Elias Antonio Pacheco e Chaves, Candido Franco de Lacerda, Candido Paes de Barros e Alexandre Siciliano (DOESP, 30 mar. 1892).

(32) Segundo Marson (2015, p. 769), a CMISP era a maior empresa do setor de máquinas, oficinas mecânicas e fundições no estado de São Paulo, de acordo com o tamanho do capital social que, no caso da Mecânica e Importadora, era de 5 mil contos de réis, sendo seguida da Cia. Mac Hardy (Campinas) com um capital de 978 contos de réis. Este domínio já podia ser evidenciado em 1893, ano em que as duas empresas divulgaram demonstrações financeiras referentes ao ano anterior e os números são os seguintes: CMISP com lucro líquido de 210 contos de réis, um ativo total de 7.794 contos, um passivo de 1.991 contos e um patrimônio líquido de 5.803 contos. Já a Cia. Mac Hardy teve os seguintes resultados: um lucro líquido de 146 contos de réis, um ativo total de 4.563 contos, um passivo de 415 contos e um patrimônio líquido de 4.148 contos (DOESP, 26 fev.1893, 29 mar. 1893). 
Em relação ao papel dos estrangeiros, vemos que já na formação da fundição paulistana J. Arbenz \& Cia. em 1884, há a presença do imigrante - o suíço João Arbenz - e de seus conhecimentos técnicos para a constituição da firma. Esta presença continuaria em 1885, quando a firma passou a se chamar Lacerda, Camargo \& Arbenz e, da mesma forma, o papel pioneiro dos imigrantes na formação industrial paulista aparece na sociedade piracicabana Engelberg, Siciliano \& Cia., em que alemães e italianos se juntaram para organizar uma firma que fabricava e vendia maquinário próprio. Ademais, o trabalho finalizou pontuando o papel do italiano Alexandre Siciliano, atuando como diretor-gerente da CMISP e responsável pela incorporação de empresas que gerou a Mecânica e Importadora.

Do ponto de vista dos fazendeiros, as evidências trazidas pelo trabalho indicam que os Lacerda Franco, uma das principais famílias ligadas ao café no Oeste Paulista, embrenharamse nos investimentos industriais desde 1884, quando Joaquim Franco Camargo Junior se uniu a João Arbenz para a criação da J. Arbenz \& Cia. Esta participação aumentou em 1885, quando Candido Franco de Lacerda - sobrinho de Joaquim - ingressou ao lado do tio e do suíço na Lacerda, Camargo \& Arbenz. O ápice deste papel industrial dos Lacerda Franco se daria a partir de 1887, quando apenas os familiares passaram a comandar a Lacerda, Camargo \& Cia., ou seja, mais do que participar de maneira acessória, temos o caso de uma grande empresa de bens de capital paulista comandada apenas por fazendeiros.

Por fim, entendemos que a principal contribuição do trabalho, inserida no campo da história de empresas, está lastreada na documentação primária das empresas analisadas. Estas evidências indicam que a evolução iniciada com a criação da J. Arbenz \& Cia. em 1884 e finalizada com a constituição da Cia. Mecânica e Importadora de São Paulo em 1890 - passando pela Lacerda, Camargo \& Cia. e a Engelberg, Siciliano \& Cia. - é uma trajetória em que a cada vez que o setor de bens de capital paulista tornava-se mais complexo, com maiores e mais modernos maquinários - na maioria importados - aumentava a demanda por elevação dos investimentos às firmas principais do setor.

Sendo assim, cada alteração societária das firmas analisadas evidenciou que o capital social das empresas se expandia em relação à precedente. Na década de 1880, esta demanda por maiores somas de capital pôde ser suprida pela família Lacerda Franco em sociedades comanditárias. Todavia, a partir do novo decênio, atinente às mudanças institucionais que estimularam as sociedades anônimas no Brasil, a criação da Cia. Mecânica e Importadora de São Paulo é um caso representativo da necessidade de ampliar a rede de investimentos, ofertar papéis ao público e, mais capitalizada, tornar a empresa a principal firma do setor de bens de capital paulista no final do século XIX e início do XX.

\section{Referências bibliográficas}

ALMARAZ, A.; SERRANO, E. Latin American economic history, business history and economics of enterprise: current trends. Journal of Evolutionary Studies in Business, v. 1, n. 1, p. 95-115, Jan./Jun. 2016. 
ARGOLO, A. Arquitetura do café. Campinas: Editora da Unicamp, 2004.

AURELIANO, L. No limiar da industrialização. Campinas, SP: Unicamp/IE, 1999.

BALANÇO LACERDA, CAMARGO \& CIA. Balanço patrimonial da oficina e fundição Lacerda, Camargo \& Cia. São Paulo: Acervo Fazenda Montevidéo, Araras-SP, 1887.

BALANÇO LACERDA, CAMARGO \& CIA. Balanço patrimonial da oficina e fundição Lacerda, Camargo \& Cia. em liquidação. São Paulo: Acervo Fazenda Montevidéo, Araras-SP, 1887.

BARBERO, M. I.; JACOB, R. Introducción. In: BARBERO, M. I.; JACOB, R. La nueva historia de empresas en América Latina y España. Buenos Aires: Temas Grupo Editorial, 2008.

BIRCHAL, S. O. O empresário brasileiro: um estudo comparativo. Revista de Economia Política, v. 18, n. 3 (71), jul./set. 1998.

CANO, W. Raízes da concentração industrial em São Paulo. T. A. Queiroz, 1981.

CARONE, E. A evolução industrial de São Paulo (1889-1930). São Paulo: Editora Senac, 2001.

CONTRATO J. ARBENZ \& Cia. Contrato social da fundição J. Arbenz \& Cia. São Paulo: Acervo Fazenda Montevidéo, Araras-SP, 1884.

CONTRATO LACERDA, CAMARGO \& ARBENZ. Contrato social da oficina e fundição Lacerda, Camargo \& Arbenz. São Paulo: Acervo Fazenda Montevidéo, Araras-SP, 1885.

CONTRATO LACERDA, CAMARGO \& Cia. Contrato social da oficina e fundição Lacerda, Camargo \& Cia. São Paulo: Acervo Fazenda Montevidéo, Araras-SP, 1887.

CONTRATO SOCIAL J. F. LACERDA \& Cia. Contrato social da casa comissária e exportadora J. F. de Lacerda \& Cia. Rio de Janeiro: Acervo Fazenda Montevidéo, Araras-SP, 1884.

CORREIO PAULISTANO. Jornal Correio Paulistano. São Paulo: várias edições, 1882-1893. Disponível em: http://bndigital.bn.br/acervo-digital/correio-paulistano/090972.

CORTES, G. S.; MARCONDES, R. L.; DIAZ, M. D. M. Mortgages for machinery: credit and industrial investment in pre-World War I Brazil. Financial History Review, 21, p. 191-212, 2014.

DALLA COSTA, A. J. História de empresas no Brasil: entre os desafios teóricos e os estudos de caso. In: SAES, A. M.; RIBEIRO, M. A. R.; SAES, F. A. M. Rumos da história econômica no Brasil. São Paulo: Alameda, 2017.

DEAN, W. A Industrialização de São Paulo. São Paulo: Difel, 1971.

DELFIM NETTO, A. O problema do café no Brasil. Rio de Janeiro: Campinas, SP: Facamp/ Editora da Unesp, 2009. 
Imigrantes e fazendeiros no alvorecer da indústria paulista: a formação da Cia. Mecânica e Importadora de São Paulo (1882-1892)

DESISTÊNCIA JOÃO ARBENZ. Distrato da sociedade J. Arbenz pela desistência do suíço João Arbenz. São Paulo: Acervo Fazenda Montevidéo, Araras-SP, 1886.

DLP LACERDA, CAMARGO \& Cia. Demonstração e lucros e perdas da oficina e fundição Lacerda, Camargo \& Cia. São Paulo: Acervo Fazenda Montevidéo, Araras-SP, 1889.

DLP LACERDA, CAMARGO \& Cia. Demonstração e lucros e perdas da oficina e fundição Lacerda, Camargo \& Cia. em liquidação. São Paulo: Acervo Fazenda Montevidéo, Araras-SP, 1892.

DOESP. Relatório da Diretoria, Balanço Patrimonial e Demonstração de Lucros e Perdas da Cia. Mecânica e Importadora de São Paulo para o ano de 1891. Diário Oficial de São Paulo, São Paulo, 30 mar. 1892.

DOESP. Relatório da Diretoria, Balanço Patrimonial e Demonstração de Lucros e Perdas da Cia. Mc Hardy \& Cia. para o ano de 1892. Diário Oficial de São Paulo, São Paulo, 26 mar. 1893.

DOESP. Relatório da Diretoria, Balanço Patrimonial e Demonstração de Lucros e Perdas da Cia. Mecânica e Importadora de São Paulo para o ano de 1892. Diário Oficial de São Paulo, São Paulo, 29 mar. 1893.

FRANCO, G. H. B. A primeira década republicana. In: ABREU, M. P. (Org.). A ordem do progresso: cem anos de política econômica republicana, 1889-1989. Rio de Janeiro: Campus, 1989.

GILA, O. A.; URQUIJO, J. R. G. El empréstito Murrieta y la fundación de las colonias Portugalete, Santurce y Algorta (Santa Fe, Argentina): 1887-1890. In: REGUERA ACEDO, I.; PORRES MARIJUÁN, R. (Ed. Lits.). Poder, pensamiento y cultura en el Antiguo Régimen. Actas de la I Semana de Estudios Históricos Noble Villa de Portugalete (Lankidetzan, n. 23), Donostia-San Sebastián, Eusko Ikaskuntza, 2002. p. 245-258.

HABER, S. The efficiency consequences of institutional change: the political economy of financial market regulation and industrial productivity growth in Brazil, 1866-1934. In: COATSWORTH, J. H.; TAYLOR, A. Latin America and the world economy since 1800. Cambridge, MA: Harvard University Press, 1998.

HANLEY, A. G. Native capital: financial institutions and economic development in Sao Paulo, Brazil, 1850-1920. Stanford, Calif.: Stanford University, 2005.

INVENTÁRIO BARÃO DE ARARY. Inventário de José de Lacerda Guimarães (Barão de Arary). Processo 226/1897, Pacote 1447/1897.

LEFF, N. H. The Brazilian capital goods industry 1929-1964. Cambridge: Harvard University Press, 1968.

LEVY, M. B. A indústria do Rio de Janeiro através de suas sociedades anônimas. Rio de Janeiro: Editora UFRJ; Secretaria Municipal de Cultura do Rio de Janeiro, 1994. 
MARCONDES, R. L.; HANLEY, A. G. Bancos na transição republicana em São Paulo: o financiamento hipotecário (1888-1901). Estud. Econ., São Paulo, v. 40, n. 1, mar. 2010.

MARSON, M. D. Origens dos empresários da indústria de máquinas e equipamentos em São Paulo, 1870-1900. Nova economia, Belo Horizonte, v. 22, n. 3, p. 481-511, dez. 2012.

MARSON, M. D. A industrialização brasileira antes de 1930: uma contribuição sobre a evolução da indústria de máquinas e equipamentos no estado de São Paulo, 1900-1920. Estudos Econômicos, São Paulo, v. 45, n. 4, p. 753-785, dez. 2015.

MARSON, M. D. Origens e evolução da indústria de máquinas e equipamentos em São Paulo, 1870-1960. 1. ed. São Paulo, SP: Annablume/Fapesp, 2017.

MELLO, J. M. C. O capitalismo tardio. Contribuição à revisão crítica da formação e do desenvolvimento da economia brasileira. Campinas: Facamp/Editora da Unesp, 2009.

MELLO, Z. M. C. Metamorfoses da riqueza: São Paulo, 1845-1895. São Paulo: Hucitec, 1990.

MILLIET, S. Roteiro do café e outros ensaios: contribuição para o estudo da história econômica e social do Brasil. 4. ed. São Paulo; [Brasilia]: Hucitec: INL, 1982.

MITCHELL, B. R. International historical statistics: Europe, 1750-2005. $6^{\text {th }}$ ed. Houndmills, Basingstoke, Hampshire; New York, NY: Palgrave Macmillan, 2007.

MUSACCHIO, A. Laws versus contracts: shareholder protections and ownership concentration in Brazil, 1890-1950. Business History Review, v. 82, n. 3, p. 445-473, 2008.

OBERACKER JÚNIOR, C. H. Vestígios suíços na história do Brasil. Revista de História USP, v. 35 n. $72,1967$.

OLIVEIRA, M. F. Cultura de consumo e indústria na São Paulo da Belle Époque (1890-1915). História Econômica \& História de Empresas, [s.1.], v. 17, n. 1, jun. 2014.

PENROSE, E. A teoria do crescimento da firma. Campinas, SP, Editora da Unicamp, 2006.

PERISSINOTTO, R. M. Classes dominantes e hegemonia na República Velha. Campinas: Ed. Unicamp, 1994.

ROCHA, I. P. Imigração internacional em São Paulo: retorno e reemigração, 1890-1920. 2007. Dissertação (Mestrado em História Econômica)-Faculdade de Filosofia, Letras e Ciências Humanas, Universidade de São Paulo, São Paulo, 2007.

RELATÓRIO SÃO PAULO. Relatório apresentado ao Presidente da República de São Paulo pela Comissão Central de Estatística. São Paulo: Typographia King, 1887.

SACHERI, G. Sulla meccanica industriale e sulle macchine agricole: relazioni dei delegati della societa alla esposizione mondiale di Vienna del 1783. Torino: Tipografia Bellardi e Appiotti, 1874. 
SAES, F. A. M. Crédito e bancos no desenvolvimento da economia paulista, 1850-1930. São Paulo: IPE/USP, 1986.

SAES, F. A. M. Estradas de ferro e diversificação da atividade econômica na expansão cafeeira em São Paulo, 1870-1900. In: SZMRECSÁNYI, T.; LAPA, J. R. A. (Org.). História econômica da Primeira República. São Paulo: Hucitec/ABPHE/Editora da Universidade de São Paulo / Imprensa Oficial, 2002.

SCHWARCZ, L. M. População e sociedade. In: SCHWARCZ, L. M. A abertura para o mundo: 1889-1930. Rio de Janeiro: Objetiva, 2012.

SILVA, G. P. As brechas ao capital nacional: a liderança da casa J. F. de Lacerda \& Cia. sobre a exportação cafeeira em Santos na década de 1880. Economia e Sociedade, Campinas, v. 24, n. 3, p. 541-571, dez. 2015.

SILVA, G. P.; COSTA, A. J. D. A formação do Grupo Votorantim: as origens de um grupo econômico brasileiro no setor têxtil de São Paulo (1891-1929). Economia e Sociedade, Campinas, v. 27, n. 1, p. 321-354, abr. 2018.

SILVA, S. Expansão cafeeira e origens da indústria no Brasil. 8. ed. São Paulo: Alfa-Ômega, 1995.

SUZIGAN, W. Indústria brasileira: origem e desenvolvimento. São Paulo: Ed. Hucitec/ Ed. Unicamp, 2000.

TANNURI, L. A. O encilhamento. São Paulo, SP: Hucitec, 1981.

VERSIANI, F.; SUZIGAN, W. O processo brasileiro de industrialização: uma visão geral. Brasília: Universidade de Brasília, Departamento de Economia, 1990. (Série Textos Didáticos, n. 10).

VOTANTES. Lista dos votantes do município de Araras (SP). Câmara Municipal de Araras (SP), 1876.

WITTER, J. S. Ibicaba revisitada. In: SZMRECSÁNYI, T.; LAPA, J. R. A. (Org.). História econômica da Independência e do Império. São Paulo: ABPHE, 1996.

WITZEL de SOUZA, B. G. Immigration and the path dependence of education: the case of German-speakers in São Paulo, Brazil (1840-1920). Economic History Review, 71, p. 506-539, 2018. 


\section{Anexo}

Demonstração da Conta de Liquidação da Lacerda, Camargo \& Cia., 31 de janeiro de 1892 valores em contos de réis correntes

\begin{tabular}{|c|c|c|c|}
\hline Débito & $\begin{array}{l}\text { Contos de } \\
\text { Réis (Rs.) }\end{array}$ & Crédito & $\begin{array}{l}\text { Contos de } \\
\text { Réis (Rs.) } \\
\end{array}$ \\
\hline \multicolumn{4}{|l|}{$\begin{array}{l}\text { Pelas quantias creditadas às } \\
\text { seguintes contas: }\end{array}$} \\
\hline Terrenos da Rua do Triunfo & 27 & \multirow{4}{*}{$\begin{array}{l}\text { Preço pelo qual vendemos à Cia. } \\
\text { Mecânica e Importadora de São } \\
\text { Paulo as nossas oficinas mecânicas, } \\
\text { fundição, armazéns e respectivos } \\
\text { terrenos, conforme escritura lavrada }\end{array}$} & \multirow{4}{*}{1.100} \\
\hline Terrenos do Brás & 31 & & \\
\hline Edifícios da Fábrica & 78 & & \\
\hline Máquinas das Oficinas & 69 & & \\
\hline Armação das Oficinas & 82 & & \\
\hline Utensílios e Móveis das Oficinas & 2 & & \\
\hline Fundição do Brás & 84 & & \\
\hline $\begin{array}{l}\text { Modelos de Madeira para } \\
\text { Fundição }\end{array}$ & 43 & & \\
\hline $\begin{array}{l}\text { Modelos de Ferro e Bronze para } \\
\text { Fundição }\end{array}$ & 21 & & \\
\hline Desvio do Brás & 8 & & \\
\hline Armazém do Brás & 36 & & \\
\hline Conserto das Casas do Brás & 3 & & \\
\hline Caixas de Ferro para Fundição & 6 & & \\
\hline $\begin{array}{l}\text { Saldo que transferimos para conta } \\
\text { Lucros e Perdas }\end{array}$ & 608 & & \\
\hline Total & 1.098 & Total & 1.100 \\
\hline
\end{tabular}

Fonte: Liquidação Lacerda, Camargo \& Cia. (São Paulo, 31 jan. 1892). 